\title{
O futebol e a sociedade global: uma reavaliação da identidade sociocultural brasileira
}

\author{
Attila Magno e Silva Barbosa*
}

\begin{abstract}
Resumo: O presente trabalho é uma reflexão socioantropológica sobre as mudanças ocorridas no modo de perceber o futebol como um exemplo da identidade cultural brasileira. O objetivo é demonstrar como tais mudanças são percebidas não como uma ruptura com alguns elementos constitutivos da tradição cultural brasileira, mas, sim, como uma reavaliação funcional de categoriais feita a partir da intensificação da lógica mercantil que passou a dominar o futebol mundial no período compreendido entre as décadas de 1970 e 1990.
\end{abstract}

Palavras-chave: futebol; globalização; reavaliação funcional de categorias.

\section{Introdução}

O futebol consolidou-se como um dos meios mais importantes de promoção da auto-imagem e de integração social do povo brasileiro. Entre outras coisas, porque permitiu a superação do caráter elitista inicial de sua prática nas primeiras décadas do século XX, quando ocorreu a inserção de jogadores negros e mestiços; fato este que possibilitou a comunicação de elementos culturais, como o jeitinho, a malandragem e o mulatismo, percebidos e celebrados no estilo de jogo criativo e inventivo praticado pelos grandes jogadores brasileiros. Outro elemento incorporado foi o personalismo patrimonialista - herança de um patronato vinculado ao viés relacional e hierárquico da sociedade brasileira - presente no comportamento de alguns dirigentes. No entanto, à medida que o Brasil vai se submetendo à nova ordem econômica mundial, tais características começam a ser ostensivamente criticadas e repudiadas por aqueles que defendem a lógica da modernização capitalista mundial.

A globalização impõe de forma sistemática uma ordem socioeconômica em que a lógica

\footnotetext{
* Doutorando em Ciências Sociais na Universidade Federal de São Carlos
}

relacional e hierárquica passa a ser intensamente vazada pela lógica impessoal e igualitária. Todavia, apesar de essa imposição ser um fenômeno fragilizador do Estado-nação, as identidades culturais locais, regionais e até mesmo nacionais parecem ser reafirmadas, contudo, sem implicar meras negações do que lhes sejam exógeno.

Nesse sentido, os valores culturais conhecidos como jeitinho, malandragem e você sabe com quem está falando $?^{1}$ - que são expressões da aversão brasileira à ordem impessoal das leis - passam a estar cada vez mais em evidência, não porque sua incidência esteja se intensificando, mas sim por terem sido colocados em xeque pelas exigências do ideário individualista e igualitário, que no Brasil tem historicamente dificuldades de se impor como eixo norteador das ações sociais.

Este artigo está dividido em quatro seções: a primeira objetiva analisar as transformações ocorridas no futebol mundial e brasileiro nas três últimas décadas do século XX; demonstraremos,

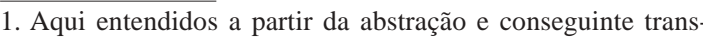
formação em categorias sociológicas, realizadas pela interpretação de Roberto DaMatta (1990), em seus estudos sobre a realidade sociocultural brasileira.
} 
na segunda, como o futebol afigura-se como um elemento de certa percepção de brasilidade e como este é submetido ao processo de globalização; a terceira consiste em uma interpretação das mudanças ocorridas na percepção dos significados que o futebol tem no Brasil, procurando entendê-las mais como um processo de reavaliação do que de eliminação de categorias simbólicas; por fim, se tecerão as considerações finais.

\section{O futebol no mundo globalizado}

A globalização como fenômeno sociológico tem o poder de desterritorializar signos, significados e manifestações culturais característicos de um grupo social ou de uma sociedade específica e de convertê-los em elementos identificáveis em outros contextos sociais. A ocorrência desse fenômeno depende da criação de uma linguagem cultural mundializada que seja a sua expressão simbólica. O objetivo é criar um território cultural onde símbolos incorporados ou não em bens materiais possam ser consumidos. Uma cultura mundializada só se faz sentida quando consegue enraizar em nossos hábitos mais prosaicos aquilo que ela desterritorializou. Ela necessita localizar-se em algum lugar e manifestar-se de alguma forma. Desse modo, o mundo pode penetrar o nosso cotidiano e, conseqüentemente, alterar a nossa compreensão de proximidade e distância (Ortiz, 1997).

No futebol, tal situação fica evidenciada quando os meios de comunicação veiculam informações sobre os principais campeonatos europeus, nos quais os melhores jogadores brasileiros atuam. Dessa forma, a audiência brasileira converte-se em mercado consumidor potencial dos produtos vinculados à imagem dos clubes europeus. A desterritorialização intensifica sua incidência sobre o futebol brasileiro a cada momento em que os jogadores mais talentosos saem do país. A maior implicação dessa situação é que tudo o que os jogadores costumavam representar em termos de identificação com a imagem do clube ${ }^{2}$ passa a deixar de ter o poder referencial de outros tempos.

2. Como foram os casos de Pelé com o Santos, Garrincha e Nilton Santos com o Botafogo, Zico com o Flamengo e Roberto Dinamite e Vasco da Gama, só para citarmos alguns exemplos.
O futebol brasileiro na década de 1990 viuse obrigado a se sujeitar de modo definitivo à lógica do mercado global, que já vinha se desenhando no continente europeu desde a década de 1970, com a constatação de que o modelo inglês de gestão baseado na fórmula dirigentes amadores e jogadores profissionais - que inspirou a organização do futebol na maior parte do mundo - entrou em descompasso com as exigências estruturais impostas pela mercantilização crescente do futebol (Helal, 1997; Proni, 2000). Antes disto, a finalidade proeminente não era gerar lucro para particulares, mas sim oferecer aos seus apreciadores o acesso ao seu espetáculo favorito e, como consequiência, produzir qualquer outra finalidade, como eventuais ganhos políticos que os dirigentes pudessem ter com as conquistas dos clubes. Segundo Helal, no Brasil, esta última situação ainda ocorre, pois, assim como acontece em outras esferas da vida social, a oposição entre o tradicional e o moderno se mantém como elemento configurador.

Até a década de 1970, o caráter comercial do futebol profissional concentrava-se na sustentação do sistema federativo de clubes. A desigualdade de potencial mercantil entre times pequenos e grandes estabelecia uma relação de interdependência, na qual os primeiros revelavam jogadores para os segundos e, em troca, recebiam uma compensação financeira. $\mathrm{O}$ futebol não era um tipo de negócio, como o que temos na atualidade, isto porque não havia por parte dos clubes planejamento de marketing, assim como qualquer outro esforço estratégico para aumentar o tamanho da torcida. $\mathrm{O}$ aumento ou diminuição das receitas vinculava-se ao desempenho da equipe na temporada. $\mathrm{O}$ futebol era uma atividade sem fins lucrativos, e os clubes dependiam da colaboração dos "sócios" para se manter. Não havia a figura do capitalista empreendedor.

Mas, no decorrer dos anos 80, a lógica do "futebol-empresa" se espraiou e fez aumentar a mercantilização dos principais campeonatos europeus, que passaram a se estruturar em virtude da demanda por transmissões televisionadas e pelo surgimento de novas opções de marketing esportivo. A globalização da economia, aliada a um ambiente político favorável para a transposição das fronteiras nacionais, conduziu 
o futebol a uma permeabilização pela lógica de valorização do capital (Proni, 2000).

No entanto, as condições materiais que viabilizaram definitivamente a transformação do futebol em elemento constitutivo de uma identidade global só se consolidaram na década de 1990, com a unificação da Europa e a criação de uma legislação trabalhista que não mais distingue os trabalhadores por suas nacionalidades dentro da Comunidade Européia. O advento da Lei Bosman ${ }^{3}$ foi produto desse contexto, quando passaram a ser considerados estrangeiros nos clubes da Comunidade apenas os jogadores de origem não-comunitária.

A consequiência visível dessa situação é a transformação de alguns clubes europeus em verdadeiras entidades globais, devido à quantidade excessiva de jogadores das mais diversas nacionalidades. Os maiores exemplos podem ser constatados nos elencos de clubes como Real Madri e Barcelona, da Espanha; Arsenal, Manchester United e Chelsea, da Inglaterra; Juventus, Milan e Inter de Milão, da Itália; Bayern de
Munique, da Alemanha, e Ajax, da Holanda. Esses times tornaram-se expressões nítidas da modernidade-mundo, como demonstra a crescente incorporação de jogadores estrangeiros no Quadro 1.

Um exemplo paradigmático dessa situação ocorreu na $27^{\mathrm{a}}$ rodada da temporada 2004/2005 da Liga Inglesa, quando o Arsenal venceu o modesto time do Crystal Palace em Londres por 5 a 1 , resultado normal devido à discrepância de poder econômico entre os dois times. Porém, o que nos interessa é que nesse jogo foi possível testemunhar um momento de plenitude da globalização. O time do Arsenal atuou sem nenhum jogador de origem britânica - em campo estiveram presentes seis jogadores franceses, três espanhóis, dois holandeses, um camaronês, um marfinense, um brasileiro e um suíço.

Com o processo de globalização, os mercados menos sólidos ficam à mercê da lógica mercantil, que expande o seu domínio ancorada em marcos regulatórios que a favorecem. No Brasil, devido às crises econômicas ocorridas

Quadro 1 - Elencos das grandes equipes européias (1995 / 2000 / 2005)

\begin{tabular}{|l|c|c|c|c|c|c|}
\hline & \multicolumn{2}{|c|}{1995} & \multicolumn{2}{c|}{$\mathbf{2 0 0 0}$} & \multicolumn{2}{c|}{2005} \\
\hline \multicolumn{1}{|c|}{ Clube } & Nacionais & Estrangeiros & Nacionais & Estrangeiros & Nacionais & Estrangeiros \\
\hline $\begin{array}{l}\text { Manchester } \\
\text { United }\end{array}$ & 22 & 2 & 22 & 12 & 12 & 14 \\
\hline Chelsea & 22 & 6 & 10 & 23 & 9 & 16 \\
\hline Arsenal & 22 & 3 & 13 & 17 & 5 & 26 \\
\hline Real Madri & 24 & 6 & 15 & 10 & 11 & 12 \\
\hline Barcelona & 18 & 6 & 13 & 13 & 9 & 13 \\
\hline Juventus & 21 & 4 & 11 & 11 & 11 & 14 \\
\hline Milan & 22 & 4 & 15 & 18 & 9 & 14 \\
\hline Inter de Milão & 23 & 5 & 11 & 15 & 4 & 19 \\
\hline $\begin{array}{l}\text { Bayern de } \\
\text { Munique }\end{array}$ & 18 & 7 & 15 & 14 & 12 & 12 \\
\hline Ajax & 19 & 6 & 13 & 12 & 13 & 16 \\
\hline
\end{tabular}

Fonte: Os números referentes ao ano de 2005 foram obtidos nos sites oficiais dos referidos clubes. Os números de 1995 e 2000 foram obtidos nos sites www.zanziball.it e www.fussballdaten.de.

3. Em 15 de novembro de 1995, o Tribunal Europeu de Justiça ordenou que o desconhecido médio Jean-Marc Bosman pudesse transferir-se do clube belga RFC Liège para a equipa francesa USL Dunkerque. Essa decisão estabeleceu que, terminado o contrato de um jogador com um time da Comunidade Européia, o atleta estaria livre para atuar em qualquer outra equipe da Comunidade sem que fosse necessário pagar qualquer indenização ao clube de sua origem. Outro desdobramento importante foi que todo jogador pertencente à Comunidade Européia poderia atuar em qualquer país membro da CE sem ser considerado estrangeiro. 
na década de 1980 e à posição ocupada na economia mundial, os clubes vêm se tornando meros fornecedores de jogadores. $\mathrm{O}$ fim da figura jurídica do "passe", com o advento da "Lei Pelé" (Lei 9.615/98), por um lado fortaleceu a posição dos jogadores de talento reconhecido, por assegurar-lhes que o vínculo com o clube passa a ser regido pelo contrato de trabalho. Por outro, porém, fragilizou a posição da maioria dos clubes brasileiros que investiam na revelação de jogadores. $\mathrm{O}$ primeiro contrato profissional de um atleta não pode mais exceder dois anos de duração, tendo o clube direito à indenização pela transferência do jogador apenas na vigência do contrato. Isso quer dizer que, mesmo quando consideramos a existência de uma administração profissionalizada e, em alguns casos, de um suporte financeiro de investidores, a negociação de jogadores é inerente à lógica que hoje domina o futebol.

Ora, o êxodo de jogadores não é um fenômeno recente no futebol brasileiro, pois nas décadas de 1920 e 1930 já ocorria. Naquele contexto, devido à falta de profissionalização dos jogadores, poucos mercados eram consideravelmente atraentes, como o italiano, já profissionalizado nos anos de 1920, o argentino, em 1931, e o uruguaio, em 1932. O êxodo de jogadores se intensificou após a Copa do Mundo realizada no Uruguai em 1930. No ano de 1931, houve a saída de 39 dos melhores jogadores brasileiros, episódio que ficou conhecido como "invasão italiana", haja vista a "presença constante de empresários italianos para contratar nossos jogadores" (Caldas, 1990, p. 261).

Assim, a profissionalização em 1933 do futebol do Rio de Janeiro e de São Paulo, a incorporação do futebol na construção de uma identidade nacional pelo Estado-Novo e as conquistas (da Copa do Mundo) que se seguiram em 1958, 1962 e 1970 corresponderam à época de ouro do futebol brasileiro, na qual o êxodo de grandes jogadores quase não existiu. Somente no início dos anos de 1970 tal migração voltou a ocorrer, porém, nesse momento, a necessidade de profissionalização da administração do futebol brasileiro foi maior, como já acontecia na Europa.

Todavia, o processo de profissionalização seria lento. A crise organizacional se aprofundou na década de 1980. Os campeonatos tornaramse cada vez mais deficitários. Grandes clubes contraíram dívidas e mais dívidas. Nesse cenário, a venda de jogadores tornou-se uma fonte de resolução dos problemas financeiros. Porém, nas décadas de 1970 e 1980, o que se negociava eram os jogadores já consagrados. ${ }^{4}$ Fenômeno bem diferente do êxodo iniciado no final dos anos de 1980, no qual os jogadores passariam a ser negociados cada vez mais jovens. ${ }^{5} \mathrm{O}$ aumento do fluxo de saída dos jogadores brasileiros para o exterior a partir do ano de $1973^{6}$ não se deu de forma contínua; até o ano de 1988 , a saída era alternada em anos de maior e de menor fluxo. Isto porque o êxodo dos jogadores estava vinculado diretamente à intensidade das crises financeiras vividas pelos clubes, que, por sua vez, estavam ligadas às crises econômicas vividas pelo país. Vejamos os dados sobre o êxodo de jogadores entre os anos 1973 e 2006 (Quadro 2).

Diante desse quadro, os torcedores brasileiros cada vez menos têm a oportunidade de ver em seu time jogadores que atuem na seleção brasileira. A criação de vínculos identitários entre os torcedores e os jogadores diminui à medida que o tempo de permanência dos jogadores nos clubes torna-se cada vez menor. O Quadro 3 diz respeito às convocações da seleção brasileira a partir da Copa de 1982, primeira em que estiveram jogadores que atuavam no exterior, e por isso considerada aqui como o marco simbólico da deflagração desse processo.

$\mathrm{O}$ atual estágio do desenvolvimento capitalista impõe a produção de uma identidade global baseada no consumo, pois, de outra forma, a ordem material que o caracteriza estaria esvaziada de conteúdo simbólico. O objetivo do

4. Falcão, transferido para a Roma, da Itália, aos 27 anos, em 1980; Zico, transferido para a Udinese, da Itália, aos 30 anos, em 1983, e Sócrates, transferido para a Fiorentina, da Itália, aos 30 anos, em 1984

5. Romário, transferido para o PSV da Holanda, aos 22 anos, em 1988; Ronaldo, transferido, também para o PSV, aos 18 anos, em 1994; e Ronaldinho Gaúcho, transferido para o PSG, da França, aos 21 anos, em 2001.

6. Ano em que a Confederação Brasileira de Futebol (CBF) passou a registrar essas ocorrências.

7. Os jogadores em questão foram Edinho, zagueiro que jogava na Udinese, e o meio-campista Falcão, que atuava na Roma, ambos na Itália. Até então, entre as Copas de 1930 e 1978, tal situação jamais tinha ocorrido. 
Quadro 2 - Êxodo de 1973 até 2006

\begin{tabular}{|c|c|}
\hline Ano & $\mathrm{N}^{0}$ de jogadores \\
\hline 1973 & 131 \\
\hline 1974 & 160 \\
\hline 1975 & 57 \\
\hline 1976 & 52 \\
\hline 1977 & 80 \\
\hline 1978 & 87 \\
\hline 1979 & 51 \\
\hline 1980 & 76 \\
\hline 1981 & 154 \\
\hline 1982 & 154 \\
\hline 1983 & 82 \\
\hline 1984 & 71 \\
\hline 1985 & 64 \\
\hline 1986 & 96 \\
\hline 1987 & 199 \\
\hline 1988 & 227 \\
\hline 1989 & 129 \\
\hline 1990 & 134 \\
\hline 1991 & 136 \\
\hline 1992 & 205 \\
\hline 1993 & 322 \\
\hline 1994 & 207 \\
\hline 1995 & 254 \\
\hline 1996 & 381 \\
\hline 1997 & 553 \\
\hline 1998 & 550 \\
\hline 1999 & 658 \\
\hline 2000 & 701 \\
\hline 2001 & 736 \\
\hline 2002 & 659 \\
\hline 2003 & 858 \\
\hline 2004 & 857 \\
\hline 2005 & 804 \\
\hline 2006 & 851 \\
\hline
\end{tabular}

Fonte: Confederação Brasileira de Futebol (CBF).
Quadro 3 - Brasil nas Copas - Origem dos convocados, 1982 a 2006

\begin{tabular}{|ccc|}
\hline Copa & $\begin{array}{c}\text { Times } \\
\text { Nacionais }\end{array}$ & $\begin{array}{c}\text { Times } \\
\text { Estrangeiros }\end{array}$ \\
\hline 1982 & 20 & 2 \\
\hline 1986 & 20 & 2 \\
\hline 1990 & 10 & 12 \\
\hline 1994 & 11 & 11 \\
\hline 1998 & 9 & 13 \\
\hline 2002 & 13 & 10 \\
\hline 2006 & 3 & 20 \\
\hline
\end{tabular}

Fonte: Confederação Brasileira de Futebol (CBF).

capitalismo globalizado, portanto, não é entender singularidades culturais, mas sim convertê-las em mercadorias. A cultura do capitalismo, pela sua exigência de racionalização formal e pragmática, define o mundo em termos de fins e meios objetivos e imediatos. Dessa forma, ela seculariza, instrumentaliza e desencanta tudo que encontra pela frente (Ianni, 1992).

A lógica do mercado, por intermédio da racionalização econômica do mundo, impõe seu domínio a tudo o que a ela não esteja adequada. Tudo que por ela é tocado parece esvair-se dos seus significados afetivos originais, não implicando perda de significados, mas sim uma reavaliação, que significa: adequação à nova ordem situacional. Como nos chama atenção Giulianotti,

A virada financeira pós-moderna é refletida na mercantilização da "herança" cultural do futebol. Os torcedores hostis podem voltar à "autenticidade" do passado, mas ainda não podem evitar o consumo de uma simulação mercantilizada. As camisas de futebol "clássicas”, do período anterior à época em que os nomes dos patrocinadores foram estampados na frente, podem ser compradas pelo correio. Antigas partidas são recicladas em retrospectivas na TV por assinatura. Os museus do futebol introduzem as próximas gerações de torcedores na arquibancada no velho estilo, por meio de modelos simulados e interativos. (2002, p. 138)

Ou seja, os significados antigos tendem a ser reavaliados porque os acontecimentos produzidos pela globalização inserem perspec- 
tivas diferentes no modo como estes devem ser vivenciados.

A globalização da informação e do conhecimento no futebol pode obscurecer as origens de estilos particulares de jogo, ao mesmo tempo permitindo a sua circulação. Todavia, lugares e sociedades diferentes geram percepções diversas dos estilos, táticas e estéticas do futebol. A globalização permite que clubes, nações e continentes tenham a experiência dessa dimensão exótica do futebol, ou seja, o encontro com as abordagens e filosofias do outro. (Giulianotti, 2002, p. 179)

Nesse sentido, o apelo que o estilo criativo do futebol brasileiro desperta no imaginário dos apreciadores desse esporte ao redor do mundo é recorrente, e, em tempos de sujeição do futebol à lógica do mercado, os objetivos dos que nele investem é tornar o espetáculo cada vez mais interessante aos olhos da audiência, vista e identificada como consumidores. No futebol brasileiro, esse processo parece tornar-se viável por conta da beleza que lhe é atribuída mundialmente. Na opinião do romancista e ensaísta inglês John Lanchester:

Nenhum outro país empenha-se tanto, ou de maneira tão determinada, em buscar essa beleza no futebol quanto o Brasil. É uma coisa ideológica, e por isso os jogadores brasileiros são tão adorados. Não na América do Sul, é claro, onde são vistos antes como representantes de uma superpotência esportiva, mas em quase todo o resto do mundo. Na verdade, a seleção brasileira de futebol ocupa uma posição única nos esportes, como exemplo de um favorito pelo qual todos simpatizam. Em geral, os torcedores, sobretudo os de futebol, odeiam os favoritos (o Real Madri na Espanha, a Juventus na Itália, o Manchester United/Chelsea na Inglaterra). Mas o time brasileiro, o único a vencer a Copa do Mundo por cinco vezes, em todos os continentes em que já foi disputada, é adorado. Por isso, muitos dos torcedores de futebol têm, em se tratando de seleções nacionais, dois times: o seu próprio e o do Brasil. (2006, p. 62)

$\mathrm{O}$ ponto fundamental nesse processo de reterritorialização promovido pela globalização do futebol é tornar o estilo brasileiro de jogar apenas mais uma das referências constitutivas do amálgama cultural que é a aldeia global. ${ }^{8}$ A ocorrência disto só é viabilizada quando os elementos que caracterizam o estilo brasileiro são fundidos a outros estilos identificáveis no contexto referencial de uma cultura mundializada.

\section{O futebol como construção simbólica da "identidade nacional"}

O dilema que a situação referida na seção anterior nos apresenta é que, se por um lado os jogadores brasileiros são cobiçados por suas habilidades, por outro, existe certo receio da parte de alguns treinadores europeus de que a resistência à rotina de treinos e a indisciplina tática também lhes sejam inerentes. Tal visão é nitidamente estereotipada, basta lembrarmos que jogadores extremamente habilidosos e de talento reconhecido como Zico e Romário têm uma origem humilde semelhante, vivenciada nos subúrbios cariocas - o primeiro no bairro de Quintino Bocaiúva e o segundo no bairro de Vila da Penha, ambos na Zona Norte. No entanto, Zico tornou-se um adepto do esforço e da dedicação aos treinos e Romário um notório opositor destes. A carreira de Zico, como nos mostra Helal (cf. Helal, Soares e Lovisolo, 2001), além de revelar o seu talento extraordinário, mostra um estilo de esportista bem mais próximo do universo social "anglo-saxônico", pois a ética do trabalho se apresenta como o elemento norteador. Já a carreira de Romário nos descortina o domínio das relações pessoais. As carreiras desses jogadores demonstram que, no Brasil, os códigos da impessoalidade das leis e das relações pessoais não são mutuamente excludentes, mas convivem como eixos conflitantes que norteiam as ações sociais. Todavia, a visão estereotipada e bastante recorrente que o mercado europeu tem do jogador brasileiro não percebe as qualidades e os defeitos, na maior parte das vezes, de modo individualizado, mas

8. Entende-se, aqui, o espaço criado pela globalização, onde valores culturais são desterritorializados de seus lugares de origem e reterritorializados em um contexto mundial, não mais como características culturais meramente locais, mas sim como referenciais da heterogeneidade cultural do mundo. 
sim como conseqüência da maneira como eles foram socializados.

Por conseguinte, o estilo brasileiro de jogar é entendido por muitos como um meio através do qual certo estilo de vida, baseado no jeitinho e na malandragem, manifesta e pode ser celebrado como estratégia de sobrevivência social. Tais características manifestam-se pela dramatização do que Lívia Barbosa (1992) chama de individualismo à brasileira, que consiste em uma visão de indivíduo baseada na capacidade de resolver problemas por meio de uma boa conversa, de jogo de cintura e não por regras universalizantes e impessoais.

Convém lembrar que o futebol, como construção simbólica, possibilitou a elaboração de "uma visão essencialmente mestiça de nossos jogadores e de nossa cultura". A construção do “'futebol-arte' foi uma corajosa afirmação do mestiço e negro brasileiros" (Gil, 1996, p. 25). $\mathrm{O}$ 'estilo brasileiro' tem nos jogadores negros e mestiços os seus principais artesãos, a sua afirmação decorre da criação de jogadas, das microinvenções do jogo, que estão associadas à individualidade de determinados jogadores (Lopes, 1994).

Essa construção, possibilitada pela afirmação das figuras do negro e do mestiço, teve na valorização da malandragem um elemento fundamental. Todavia, no Brasil, o futebol-arte não se apresentou como uma fórmula unívoca, ele foi sendo pensado e adequado aos esquemas culturais das principais regiões que deram base à idéia de futebol como elemento constitutivo da identidade nacional. Como mostra Giulianotti,

[...] as vastas diferenças econômicas, sociais e geoclimáticas do Brasil significam que a posição do malandro no imaginário cultural é cortada transversalmente por outras tradições regionais. Os times do Rio são verdadeiros pioneiros da estética sul-americana, através de um estilo exibicionista e rítmico, fluindo entre a construção cuidadosa e o ataque repentino. Na imensidão urbana de São Paulo, o futebol é mais industrioso, rotinizado e geometricamente fixado. As equipes de Porto Alegre empregam uma abordagem mais "uruguaia", jogando sem astros e freqüentemente com uma determinação violenta de vencer, não importando os meios. (2002, p. 181)
Devido a esse tipo de ocorrência, Norbert Elias (cf. Elias \& Dunning, 1992) advoga a tese de que a qualidade de um jogo e o prazer que ele desperta na audiência dependem das tensões que provoca. A sensibilidade desenvolvida em uma sociedade ou grupo social determina a estética à qual os seus membros aderem. Isto é crucial para entender as diferenças entre os estilos de jogo tanto entre países, como entre regiões dentro de um mesmo país, como é o caso do Brasil. Nesse sentido,

[...] a estética futebolística, um caso particular de estética esportiva, é algo que a perspectiva formalista não pode captar. Há um sentido profundo nos embates, um pano de fundo cultural no qual os sentimentos de pertença e o próprio gosto pelo futebol estão alicerçados. O caráter democrático - em contrapartida ao autoritarismo dos cartolas que manipulam as regras - torna cada torcedor um comentador, um crítico autorizado para falar em estilos de jogo e associá-los a certas categorias sociais. O futebol-arte revelaria o caráter carioca, o futebol-força, a maneira como são os gaúchos e assim por diante. (Damo, 2001, p. 88)

Para entender melhor isto, acreditamos ser necessário fazer referência ao conceito de dramatização utilizado por Dumont (1993) e DaMatta $(1982 ; 1986 ; 1990)$. Para esses autores, a dramatização apresenta-se como um traço distintivo do ritual, definido como o oposto da rotina. O ritual, por meio da dramatização, coloca em destaque determinados elementos ou relações de uma sociedade ou grupo social, condensando-os e expondo-os como fenômenos que individualizam uma coletividade. $\mathrm{O}$ 'estilo brasileiro' é tido como aquele que enfatiza a importância de exibir-se para o público, buscando valorizar o espetáculo. Aimprovisação é o ponto culminante, e ela se faz presente em um drible ou em uma jogada imprevisível. As jogadas improvisadas e inusitadas constituem a essência do futebol-arte. Nesse sentido, como demonstra DaMatta (1982), o futebol é mais uma fonte de individualização e de expressão individual do que um instrumento de coletivização em nível pessoal ou das massas, ou seja, por seu intermédio o povo brasileiro pode se sentir individualizado e personalizado nas jogadas dos grandes craques. 
Porém, não podemos perder de vista que, como expressão de identidade nacional, o futebol foi construído a partir do eixo Rio-São Paulo. Isto ocorreu devido ao fato de a cidade do Rio de Janeiro ter sido capital federal até o ano de 1960 e de o estado de São Paulo exercer a liderança econômica nacional. Tal situação teve papel central na definição da simbologia que tradicionalmente caracteriza o chamado 'estilo brasileiro' de jogar. Muito embora tenhamos ciência desse fato, não podemos negligenciar que, mesmo sendo tal construção um produto validado no referido eixo, o futebol foi incorporado como uma expressão de certa noção de brasilidade em todas as regiões do país; um elemento de integração nacional. Ou seja, mesmo que estejamos diante de uma construção ideológica, nada obsta que esta também tenha seus elementos constitutivos dramatizados, independentemente das variações culturais existentes entre as regiões do país.

Peguemos, para efeito de ilustração, o caso da fórmula "você sabe com quem está falando?", característica que, mesmo fragilizada nos dias de hoje no âmbito da sociedade, ainda se faz presente no futebol brasileiro. Nas palavras de DaMatta, "a fórmula "você sabe com quem está falando?' é uma função hierarquizadora e da patronagem que permeia nossas relações diferenciais e permite, em conseqüência, o estabelecimento de elos personalizados em atividades basicamente impessoais" (1990, p 159). Ela pode ser expressa sem ser proferida verbalmente, basta apenas que alguém se coloque em uma situação de superioridade diante de uma regra impessoal que, em princípio, deveria ser aplicada a todos. Assim como o jeitinho, o 'você sabe' só pode existir em universos contaminados pela ótica individualista, impessoal, igualitária e anônima. Um universo social holista e hierárquico prescinde de qualquer um desses mecanismos, pois as posições dos interlocutores já estão previamente dadas (Barbosa, 1992, p. 80).

No futebol, assim como na realidade social, não são todos que podem lançar mão desse recurso com legitimidade. Somente aqueles que são considerados como acima dos demais dentro de uma hierarquia estabelecida pela condição individual podem usá-la, ou seja, os grandes craques. Esses jogadores podem usá-la porque geralmente contam com a anuência da torcida $\mathrm{e}$, principalmente, dos dirigentes que os percebem em situação diferenciada por causa de suas qualidades técnicas e de sua capacidade de decidir as partidas em favor do time. Por tais motivos, eles são tidos como jogadores diferenciados e que não precisam se sujeitar às mesmas regras que se aplicam aos demais jogadores do grupo. Se, no futebol brasileiro, somente na década de 1990 (vide as polêmicas criadas pelos casos de Romário, Edmundo e Djalminha) ${ }^{9}$ tal comportamento passou a vir à tona de forma recorrente, devido às críticas severas de boa parte da imprensa, foi porque nesta década o lado relacional da sociedade brasileira começou a mais claramente a perder espaço diante do lado igualitário, que se impõe cada vez mais como condição básica da ordem social capitalista.

Outra característica a ser duramente criticada desde os anos 1970 é o estilo de administração amadora dos dirigentes de federações e clubes, o qual é considerado, pela maior parte da imprensa esportiva, o principal fator de inviabilidade da modernização do futebol brasileiro. Ademais, essa desorganização do futebol brasileiro já era algo que a imprensa brasileira denunciava antes mesmo da crise deflagrada na década de 1970. Por exemplo, os livros Os subterrâneos do futebol, escrito por João Saldanha em 1963, e O negro no futebol brasileiro, escrito por Mário Filho em 1947 e reeditado em 1964, já denunciavam o arcaísmo e a obsolescência da administração do futebol brasileiro. Principalmente no que dizia respeito à falta de um calendário racional nos campeonatos disputados no país, o qual tinha as datas dos jogos mudadas de acordo com os interesses dos clubes e, em muitos casos, um número excessivo de jogos, o que prejudicava o desempenho dos jogadores e conseqüentemente do espetáculo. Segundo Helal:

9. Jogadores que se notabilizaram por exigir tratamento diferenciado em relação aos outros jogadores dos elencos das equipes em que atuavam, por se perceberem como mais habilidosos tecnicamente e por terem como conseqüência disto certa anuência de dirigentes e torcedores. 
[...] o que deflagrou a crise a partir de meados da década de 1970 foram as tendências universais à profissionalização dos dirigentes, à racionalização e à impessoalização na forma de gerenciar. Tendências estas que entraram em choque com a administração "tradicional", tornando a desorganização mais evidente. (1997, p. 42)

Para se ter uma idéia, somente em maio de 1982, o Conselho Nacional de Desportos (CND) aprovou o uso de publicidade nos uniformes e apenas em 1987, com a Copa União organizada pelo Clube dos $13,{ }^{10}$ os jogos de futebol passaram a ser televisionados ao vivo, isto porque a mentalidade tradicional via nas transmissões um estímulo para a diminuição de público nos jogos que fossem realizados no mesmo horário. Tais situações desde a década de 1970 já eram permitidas nos campeonatos europeus, o que possibilitou aos clubes importantes fontes de receita.

As críticas feitas pela imprensa vieram se desenhando desde a década de 1970, pautadas na convicção de que a desorganização administrativa não consubstanciava uma visão empresarial profissional que permitisse ao futebol brasileiro uma maior proteção diante das crises econômicas do país. Na representação da mídia, a lógica dos dirigentes amadores e jogadores profissionais e uma legislação esportiva produzida por regimes autoritários eram identificadas como os fatores que impediam a adequação da organização do futebol brasileiro aos moldes preconizados pelo estilo de modernização que se processava nos principais campeonatos europeus. Pois, no Brasil, o que imperava eram a política da troca de favores, conciliação e paternalismo (Helal, 1997).

10. Movimento iniciado em julho de 1987 pelos treze clubes de maior torcida no país: Botafogo, Flamengo, Fluminense, Vasco, Corinthians, Palmeiras, Santos, São Paulo, Atlético Mineiro, Cruzeiro, Grêmio, Internacional e Bahia. O objetivo principal era resolver os problemas de sucessivos campeonatos brasileiros deficitários, em que a queda de público foi identificada como consequiência de um calendário desorganizado e de campeonatos com número excessivo de clubes, os quais não proporcionavam espetáculos que tivessem apelo popular devido a pouca representatividade de suas torcidas. Em 1987, o Clube dos 13 resolveu realizar a chamada Copa União, que inicialmente não teve apoio da Confederação Brasileira de Futebol $(\mathrm{CBF})$, mas posteriormente deu o seu aval, com a entrada de Goiás, Santa Cruz e Coritiba.
Ora, os membros da imprensa esportiva brasileira funcionam como mediadores simbólicos ${ }^{11}$ entre o futebol e aqueles que o apreciam. A interpretação dada por eles não é uma simples decorrência de como percebem o esporte. Os discursos de modernização por eles proferidos podem ser vistos não apenas como meras justificativas de um modelo de organização do futebol, mas também como discursos legitimadores de uma ordem política e econômica produzida pela globalização. Para efeito de ilustração, a opinião do jornalista esportivo Matinas Suzuki Jr., em artigo publicado no dia 9 de janeiro de 1997, no jornal Folha de S. Paulo, nos serve como uma referência da representação dominante da mídia esportiva no período pré-Lei Pelé: “A modernização do futebol é igual à modernização do país. Ela requer uma redefinição de papéis, públicos e privados".

No entanto, a imprensa especializada deve ser considerada apenas como um dos agentes envolvidos na negociação intensa e inacabada que vem a ser a construção do futebol como elemento simbólico da cultura brasileira. A compreensão da dinâmica estrutural desse processo deve estar baseada em uma perspectiva de análise na qual entender a negociação entre as representações dos agentes sociais envolvidos é fundamental para a apreensão das múltiplas dimensões que constituem o campo profissional do futebol no Brasil. Nesse sentido, a tríade configurada pelos atores sociais envolvidos é o fator basilar para a definição dos conteúdos simbólicos das "situações rituais" que caracterizam as formas de representação do futebol. Os atores sociais envolvidos nessa negociação de significados são os profissionais, que correspondem a todos aqueles que interferem diretamente no resultado dos jogos (jogadores, técnicos, árbitros, dirigentes, preparadores físicos, fisioterapeutas etc.); os especialistas ou cronistas esportivos, profissionais da mídia (narradores, comentaristas e repórteres) que atuam como intérpretes dos jogos, constituindose como mediadores simbólicos entre o evento e os torcedores, e os próprios torcedores, os

11. Os mediadores simbólicos, segundo Renato Ortiz, "são os responsáveis por descolarem as manifestações culturais de sua esfera particular e as articularem a uma totalidade que as transcende" (1994, p. 141). 
que compartilham o universo do futebol por via da emoção (Toledo, 2000; 2002). Infelizmente, para os propósitos deste artigo, não podemos nos ater mais profundamente sobre essa questão, mas é preciso que vejamos nessa tríade de autores a qual Toledo se refere o eixo central do processo de reavaliação das categorias simbólicas que são tidas como representações do 'estilo brasileiro' de jogar.

\section{A reavaliação do futebol como categoria simbólica}

O futebol adquiriu a importância que tem para os brasileiros por refletir alguns elementos culturais tidos a partir de uma construção simbólica como caracterizadores de um estilo de vida compreendido como sinônimo de brasilidade. Os estilos de jogo e as formas de organização do futebol como atividade esportiva e espetáculo retratam padrões culturais de cada sociedade (Lever, 1983). Ou seja, assim como no futebol-arte podemos perceber a celebração de determinadas características culturais, também na forma de organização é possível ver o ajuste ao dilema brasileiro. Um futebol que transita entre a lógica da universalidade e impessoalidade das leis, caracterizadoras da modernização capitalista, e a lógica das relações pessoais e da hierarquia, reminiscências de um sistema tradicional baseado na troca de favores e no personalismo patrimonialista.

Para Helal (1997), o "tradicional" e o "moderno" no futebol brasileiro coexistem de um modo mais complexo do que o vivenciado na realidade cotidiana. O "moderno" que se manifesta na exigência de um maior nível de profissionalização e comercialização tende a se misturar com uma administração baseada na paixão, no relacionamento pessoal, na troca de favores e na proibição do profissionalismo dos dirigentes. Assim como a maior racionalização do jogo, característica também moderna, se contrapõe aos aspectos valorizados na visão tradicional do futebol. Por outro lado, Proni nos chama atenção para o fato de que "o "ideal modernizante' vai sendo redefinido com o passar do tempo, do mesmo modo que a tradição pode ser recorrentemente reinventada" (2000, p. 169).
[...] o que ora é visto como moderno pode se transmutar, num momento posterior, em emblema do tradicionalismo. Quando foi introduzido, o modelo amador elitista era um signo de modernidade; nos anos vinte, tornou-se a bandeira do conservadorismo. Da mesma forma, a "ética dual" foi entendida como o modelo perfeito para a democratização do futebol durante décadas; depois se tornou, nos anos noventa, não só um modelo ultrapassado, mas a própria encarnação do atraso. E a presença de interesses comerciais na organização do esporte, que era vista como prejudicial nos anos sessenta, foi eleita recentemente como a sua redentora. (Proni, p. 169)

O sentido conferido por Proni à redefinição do "ideal modernizante" e à reinvenção recorrente da tradição corresponde a uma ruptura seletiva, na qual elementos não mais ajustáveis tornam-se inadequados diante de determinadas situações e, portanto, passíveis de transmutação. Aqui recorremos ao que diz Marshall Sahlins: "um evento é definido como a relação entre o acontecimento e a estrutura (ou estruturas): o fechamento do fenômeno em si mesmo enquanto valor significativo ao qual se segue sua eficácia histórica específica" (1994, p. 15). A mudança trazida por um evento não implica necessariamente a eliminação das categorias anteriormente contidas na estrutura simbólica, mas, sim, muitas vezes, uma readequação do conteúdo destas às novas exigências históricas. Tal situação é definida por Sahlins como uma "reavaliação funcional de categorias". Para nós, quando consideramos essa lição, entendemos que as mudanças ocorridas na estrutura simbólica de uma sociedade tornam os significados antigos inadequados diante dos novos eventos, logo, passíveis de modificações com vista a se readequarem à ordem situacional. O estabelecimento de novas ordens situacionais é um fato contínuo nas sociedades humanas, porém estas nunca são novidades integrais, pois, como nos demonstra Sahlins:

[...] a ação simbólica é um composto duplo, constituído por um passado inescapável e por um presente irredutível. Um passado inescapável porque os conceitos através dos quais a experiência é organizada e comunicada procedem do esquema cultural preexistente. E um 
presente irredutível por causa da singularidade do mundo em cada ação: a diferença heraclitiana entre a experiência única do rio e seu nome. A diferença reside na irredutibilidade dos atores específicos e de seus conceitos empíricos que nunca são precisamente iguais a outros atores ou outras situações - nunca é possível entrar no mesmo rio duas vezes. (1994, p. 189)

Ao mesmo tempo em que o passado se faz presente como referência ordenadora para as ordens situacionais de épocas subseqüentes, os significados que o caracterizavam passam a estar sujeitos a modificações e readequações produzidas pelos grupos sociais e pelos indivíduos que vivenciam de modo particular as categorias culturais.

$\mathrm{Na}$ realidade imposta pelo capitalismo global, o jeitinho e a malandragem devem ser deixados de lado no que concerne ao funcionamento da vida econômica, pois o comportamento esperado nessa esfera é a sujeição dos indivíduos à universalidade das leis e à racionalidade técnica. Todavia, no âmbito de qualquer manifestação cultural que almeje conquistar o interesse de certa audiência, como é o caso do futebol, a capacidade de improvisação não precisa ser eliminada, basta apenas estar a serviço do coletivo, ou seja, o craque não deve jogar como se a vitória dependesse somente dele.

Nesse contexto, desde a derrota na Copa do Mundo de 1982, o estilo brasileiro de jogar veio assimilando gradativamente um padrão no qual o resultado passa a ser o objetivo maior. $\mathrm{O}$ maior exemplo disto é o título obtido na Copa do Mundo de 1994, pois a sensação que ficou para muitos foi certa frustração de ter visto a seleção vencer não no estilo do futebol-arte, mas, sim, no estilo do futebol-força, que é considerado uma característica do futebol europeu e não do futebol brasileiro. A campanha brasileira, apesar de invicta, não conseguiu ter a adesão entusiasmada de outros tempos, pois o futebol apresentado pela equipe do treinador Carlos Alberto Parreira pautou-se pela disciplina tática e por uma mentalidade defensiva com momentos esporádicos de brilhantismo individual, na maioria das vezes, protagonizados pelo atacante Romário.

É preciso entender que a particularidade do estilo de jogar brasileiro foi uma decorrência de certa percepção dominante que viu no futebol um meio de manifestação de determinados elementos culturais tidos como signos de brasilidade. Isso significa dizer que o futebolarte como sinônimo do futebol brasileiro foi uma construção simbólica que se fez a partir de uma série de oposições com o futebol europeu, que é entendido como o locus das variações do futebol-força (Damo, 1999).

Como vimos anteriormente, a intensificação da lógica mercantil advinda com o processo de globalização da economia submete os valores antigos do futebol - provenientes de uma época romântica em que o futebol-arte falava mais alto que o futebol-força - a uma reavaliação que torna possível sua adequação às expectativas de retorno financeiro dos investidores. Assim, a ousadia decorrente das jogadas de efeito se vê submetida aos esquemas táticos; a liberdade de criação individual tem de ser adequada aos interesses da equipe, e o resultado passa a ser mais importante que jogar bonito, ${ }^{12}$ até mesmo porque vários interesses passam a depender diretamente dos resultados obtidos pelos times. Isto implica dizer que certa cautela passa a ser inerente ao momento de criação de esquemas táticos e de estratégias de jogo por parte dos treinadores. Sobre isto, o depoimento de Zico um dos grandes representantes do futebol-arte do passado, e que em 2006 foi treinador da seleção japonesa durante a Copa do Mundo -, em entrevista concedida ao canal Band Sports, em 12/7/2006, é bastante elucidativo sobre o predomínio do futebol-força sobre o futebol-arte na Copa do Mundo de 2006:

Aqueles que estão achando que o futebol vai voltar àquela beleza, àquela plástica, ver constantemente uma atuação como a do Zidane contra o Brasil, isso é coisa rara hoje em dia, infelizmente para quem gosta do futebol, porque hoje o que predomina é a força física e a altura; é o condicionamento físico. A Copa do Mundo apenas constata isto. Aqueles que estão aí acompanhando o futebol já sabiam que esse equilíbrio ia acontecer, e a tendência é cada vez

12. No imaginário brasileiro, jogar bonito significa dar espetáculo para a platéia, jogando um futebol que envolva tecnicamente o adversário com toque de bola refinado e com jogadas de efeito, as quais demonstrem a criatividade dos nossos jogadores. 
mais diminuir a média de gols em competições e principalmente em competições como a Copa do Mundo e a Champions League, que tem muito interesse em jogo. Futebol que é bom, a gente vê só nas peladas.

Entretanto, isto não quer dizer que no futebol brasileiro as categorias simbólicas antigas tenham sido simplesmente substituídas por novas que estejam em melhor sintonia com a atual situação. Ao invés de eliminadas, podem estar sendo reavaliadas, pois o passado é sempre a referência sobre a qual o presente se constrói a diferença é que os atores que vivenciam os significados o fazem sob as exigências de suas épocas, sob circunstâncias históricas específicas. Isto significa que, em tempos de mercantilização do futebol, a preocupação crescente com a obtenção de resultados tornou-se o elemento condicionante das formas de jogar; as vitórias futebolísticas hoje não mais se esgotam em uma dimensão meramente simbólica, elas se tornaram meios de viabilização de todo um conjunto de interesses econômicos. Como nos diria Bourdieu (1990), o esporte, assim como a obra musical e o texto filosófico, mesmo que tenha determinadas propriedades intrínsecas que definam os limites dos seus usos sociais, está aberto a uma diversidade de usos e pode vir a ser marcado a cada instante pelo uso dominante.

Nesse sentido, apesar das variações regionais nos estilos de jogar que sempre estiveram presentes no futebol brasileiro, na atualidade, muitos são os que se ressentem da perda dos vínculos com a plasticidade de um estilo de jogo que teve nos anos de 1950 e 1960, principalmente no eixo Rio-São Paulo, o seu apogeu e que, por essa razão, a imprensa esportiva dessas localidades passou a identificar esse estilo como uma expressão da identidade nacional. Mas não podemos esquecer que, naquele tempo, as tecnologias informacionais disponíveis não permitiam um intercâmbio tão intenso de informações sobre esquemas táticos, estilos de jogo, preparação física e, principalmente, conhecimento sobre as habilidades individuais de cada jogador.

Como nos chamam atenção Soares e Lovisolo, "hoje, se lamenta a perda de identidade, estamos num momento em que o futebol apresenta características mais globalizadas e as equipes do mudo inteiro utilizam modelos semelhantes" (2003, p. 140-141). Nessa mesma linha, Giglio nos lembra que "atualmente não podemos mais encarar o binômio futebol-arte e futebol-força como uma oposição. O futebol brasileiro apresenta elementos dos dois estilos de jogo, assim como o futebol europeu apresenta algumas características do estilo brasileiro" (2005, p. 69).

Essa situação nos faz lembrar a função integradora que a cultura tem. E que o processo de socialização trabalha no sentido de ajustar os comportamentos individuais às exigências impostas pelos padrões culturais dos grupos sociais nos quais os indivíduos estão inseridos. Como se não bastasse o modo diferenciado como cada grupo social vivencia os significados contidos no esquema cultural de uma sociedade, ainda temos a incidência dos riscos subjetivos, pois cada indivíduo pode introjetar e interpretar de modo diferenciado as categorias que lhes são apresentadas a partir dos esquemas culturais que lhes são mais próximos (Sahlins, 1994).

Desse modo, entendemos que, no Brasil, temos uma situação que se configura da seguinte maneira: o esquema cultural do futebol ainda fala de jeitinho, de malandragem e até mesmo do indesejado você sabe com quem está falando?. No entanto, o modo como estas categorias são percebidas dependem de como cada região ou grupo social vivencia os dois eixos de classificação que norteiam a realidade social brasileira: o relacional e hierárquico e o individualista e igualitário. Além disso, as interpretações realizadas pelos grupos sociais estão sujeitas às interpretações individuais desses dois eixos. Sempre, é claro, considerando a ordem situacional em que tais interpretações são realizadas, seja esta regional, nacional ou global.

\section{Considerações finais}

A intenção deste artigo foi destacar no futebol uma instância rica em significados que possibilita interpretar uma parte da realidade cultural brasileira. Parafraseando Clifford Geertz, é possível dizer que tanto a briga de galo para os balineses, como o futebol para os brasileiros não significam "uma imitação da pontuação da vida social destes povos, tão pouco 
uma mera representação, nem mesmo uma expressão delas, mas sim um exemplo delas, cuidadosamente preparado" (1989). De outra maneira, o fato de o brasileiro se ver como possuidor do melhor futebol do mundo pode ser entendido como uma história que nós contamos a nós mesmos. Isto porque nele percebemos alguns elementos que caracterizariam certas noções de brasilidade que foram construídas como expressões de certa identidade nacional. Porém, tais aspectos não se apresentam de modo estático, posto que sejam reavaliados de acordo com as exigências de cada mudança ocorrida na ordem situacional; nos dias atuais, carregada de sentidos globais.

O contexto político-econômico atual não mais demanda a construção de uma identidade nacional - como ocorreu entre as décadas de 1930 e $1970 .{ }^{13}$ A situação atual pleiteia um engendramento de uma identidade global, um produto das referências criadas pela mundialização a partir da seleção de determinados padrões culturais. Aí, o objetivo é colocar o futebol brasileiro em sintonia com as exigências impostas pela globalização, mesmo que isso custe uma relativa descaracterização aos olhos de alguns. Muito embora isto não signifique uma anulação dos significados antigos, mas sim uma reavaliação destes, uma readequação à nova ordem situacional.

O futebol, em tempos de capitalismo globalizado, adquiriu o caráter de um produto a ser comercializado mais do que um mecanismo de expressão de identidades culturais; o principal interesse do mercado é extrair do futebol o máximo de lucro possível. No entanto, convém lembrar que a obtenção de lucro só pode se viabilizar porque o futebol realmente é uma fonte de expressão de identidades, pois o interesse que ele desperta, na maioria dos povos que o apreciam, é anterior à sua conversão em mera mercadoria.

13. Por ser um dos signos de brasilidade mais expressivos, o futebol foi bastante utilizado como um meio de veiculação ideológica nesse período, vide os casos de Getúlio Vargas no período do Estado-Novo, com a ideologia da mestiçagem servindo de suporte simbólico para a integração nacional e para o projeto de modernização do país, e do general Médici, que usou a conquista da Copa do Mundo de 1970 para exaltar o modelo político e econômico do Estado-nação brasileiro no regime militar.
Em nosso entendimento, o futebol, como qualquer atividade humana, não tem nenhum sentido intrínseco, pois como toda atividade sobre a qual incide o olhar humano é o uso que dela fazemos, a partir de um esquema sociocultural determinado, que lhe confere significado. Se hoje os usos conferidos ao jogo parecem globais, é porque eles também o são e não apenas o são - os olhares nacional e local não se perdem. Se hoje o futebol é regido pela lógica mercantil modernizadora, isso não elimina do imaginário brasileiro a estética tradicional que o constituiu como estilo, apenas a reavalia funcionalmente, tendo em vista sua adequação à nova ordem situacional. Até porque o tear da cultura tece fios difíceis de serem rompidos por completo.

\begin{abstract}
The present article is an anthropological reflection about the changes occurred in the way of to realize the football while an example of the Brazilian cultural identity. The goal is try to understand how such transformations are realize not like a rupture with the constitutive elements of the Brazilian culture, but yes, like a functional revaluation of categories made as from of intensification of the mercantile logical that passed to rule the world soccer on period that comprised between decades of 1970 and 1990.
\end{abstract}

Key-words: football (soccer); globalization; functional revaluation of categories.

\section{Referências}

BARBOSA, Lívia. O jeitinho brasileiro. Rio de Janeiro: Campus, 1992.

BOURDIEU, Pierre. Programa para uma sociologia do esporte. In: BOURDIEU, Pierre. Coisas ditas. São Paulo: Brasiliense, 1990. p. 207-220.

CALDAS, Waldenyr. $O$ pontapé inicial: memória do futebol brasileiro. São Paulo: Ibrasa, 1990.

DAMATTA, Roberto. Esporte na sociedade: um ensaio sobre o futebol brasileiro. In: DAMATTA, Roberto et al. Universo do futebol. Rio de Janeiro: Pinakotheke, 1982. p. 19-42.

Explorações: ensaios de sociologia interpretativa. Rio de Janeiro: Rocco, 1986.

Carnavais, malandros e heróis: para uma sociologia do dilema brasileiro. 5. ed. Rio de Janeiro: Editora Guanabara, 1990. Rocco, 1991.

O que faz o brasil, Brasil?. Rio de Janeiro: 
DAMO, Arlei S. Ah! Eu sou gaúcho! O nacional e o regional no futebol brasileiro. Estudos históricos, Rio de Janeiro, n. 23, 1999, p. 87-118.

Futebol e estética. São Paulo em Perspectiva, 15(3), 2001, p. 82-91.

DUMONT, Louis. $O$ individualismo: uma perspectiva antropológica da ideologia moderna. Rio de Janeiro: Rocco, 1993.

ELIAS, Norbert; DUNNING, Eric. A busca da excitação. Lisboa: Difel, 1992.

GIL, Gilson. O drama do "futebol-arte": o debate sobre a seleção nos anos 70. Revista Brasileira de Ciências Sociais, São Paulo, 1996, n. 25, p. 70-84.

GEERTZ, Clifford. A interpretação das culturas. Rio de Janeiro: Editora Guanabara, 1989.

GIGLIO, Sérgio Settani. Futebol-arte ou futebolforça? O estilo brasileiro em jogo. In: DAOLIO, Jocimar (Org.). Futebol, cultura e sociedade. Campinas: Autores Associados, 2005.

GIULIANOTTI, Richard. Sociologia do futebol. São Paulo: Nova Alexandria, 2002.

HELAL, Ronaldo. Passes e impasses: futebol e cultura de massa no Brasil. Petrópolis: Vozes, 1997.

. As idealizações de sucesso no imaginário brasileiro: um estudo de caso. In: HELAL, Ronaldo.; SOARES, Antonio Jorge.; LOVISOLO, Hugo. A invenção do país do futebol. Rio de Janeiro: Mauad, 2001.p. 135-147.
IANNI Otávio. A sociedade global. Rio de Janeiro: Civilização Brasileira, 1992.

LANCHESTER, John. Magos da bola: uma paixão mundial. National Geografhic, ano 7, n. 75, 2006, p. 57-62.

LEVER, Janet. A loucura do futebol. Rio de Janeiro: Editorial Record, 1983.

LOPES, José Sergio Leite. A vitória que incorporou a pelada. Revista USP, Dossiê Futebol, 1994.

ORTIZ, Renato. Cultura brasileira e identidade nacional. São Paulo: Brasiliense, 1994.

. Um outro território: ensaios sobre a mundialização. São Paulo: Olho Dágua, 1997.

PRONI, Marcelo Weishaupt. A metamorfose do futebol. Campinas: Unicamp-Instituto de Economia, 2000.

SAHLINS, Marshall. Ilhas de história. Rio de Janeiro: Jorge Zahar, 1994.

SOARES, Antônio J.; LOVISOLO, Hugo R. Futebol: a construção histórica do estilo nacional. Revista Brasileira de Ciências do Esporte, São Paulo, n. 1, 2003, p. 129-143.

TOLEDO, Luiz Henrique de. No país do futebol. Rio de janeiro: Jorge Zahar, 2000.

Lógicas no futebol. São Paulo, Hucitec/

Fapesp, 2002. 